Ann. Biol. anim. Bioch. Biophys., 1979, 19 (3 B), 959-963

\title{
Correlation between plasma high-density lipoprotein concentration and lipid digestive efficiency in swine with biliary fistulae
}

par Annie MOUGIN-SCHUTZ, Anik GIRARD-GLOBA, T. CORRING *

Centre de Recherches sur la Nutrition du C.N.R.S., 9, rue Jules-Hefzel $\mathbf{9 2 1 9 0}$ Meudon-Bellevue

* Laboratoire de Physiologie de la Nutrition, I.N.R.A., 78350 jouy-en-josas, France.

Summary. Five Large-White pigs weighing $55 \mathrm{~kg}$ were fitted with permanent biliary fistualae. During 8-day periods, each animal was successively submitted to total diversion, duodenal reintroduction of its own bile and reintroduction of a saline solution equal in amount and concentration to the secreted bile. Lipid digestibility was monitored during the last 5 days of each period. Plasma lipids and lipoproteins were determined on the last day of each period. Total soluble lipid digestive efficiency values were lowered by bile diversion, whether compensated or not. The moderate and non-significant decline of the cholesterol level indicated good loss compensation by synthesis. The phospholipids decreased in the same proportions, accompanied by a significant drop of the HDL $(p<0.05)$ in bile-deprived animals. There was a significantly high correlation between lipid digestive efficiency and the plasma phospholipid level and between that efficiency and the HDL level. Therefore, lipid absorption, circulating phospholipids and plasma HDL seemed to be closely related. We propose that a large part of the HDL was synthesized in the intestinal wall during absorption.

\section{Introduction.}

The diversion of bile from the digestive tract considerably reduces absorption of lipids and results in the net loss of large amounts of cholesterol. Cholesterol deprivation, obtained through feeding cholestyramine, is compensated for in rats by increased synthesis (Shefer ef al., 1972), restoring the normal circulating levels of cholesterol. The experiment reported here was designed to evaluate the impact of total biliary diversion on plasma lipid and lipoprotein concentrations.

\section{Material and methods.}

We used 5 castrated Large-White male pigs weighing $55 \mathrm{~kg}$ at the beginning of the experiment and fed a balanced diet containing 21 p. 100 peanut oil. Bile was collected continuously. During 8-day periods, each animal was submitted successively the follow- 
ing procedures : (i) reintroduction of its own bile, (ii) reintroduction of a saline solution equal in amount and concentration to the secreted bile, (iii) no reintroduction. Apparent lipid digestibility was determined during the last 5 days of each experimental period.

Blood was collected from the jugular at $9: 00 \mathrm{a}$. m. (2 hrs after the morning meal) on the last day of each period. Serum lipids were analyzed by routine procedures for triglycerides (Boehringer, Kit no. 15989), cholesterol (Abell ef al., 1952) and phospholipids (Bartlett, 1959). Total lipoproteins were isolated from serum by flotation at $d 1.21$ (48 hrs $\times 38000 \mathrm{rpm}$ in the Sw 41 Spinco rotor). Individual classes were separated by a gradient procedure. Typical profiles of optical density recorded at $280 \mathrm{~nm}$ are shown in figure 1. The protein in each fraction was assayed by the Lowry procedure (Lowry et al., 1951).
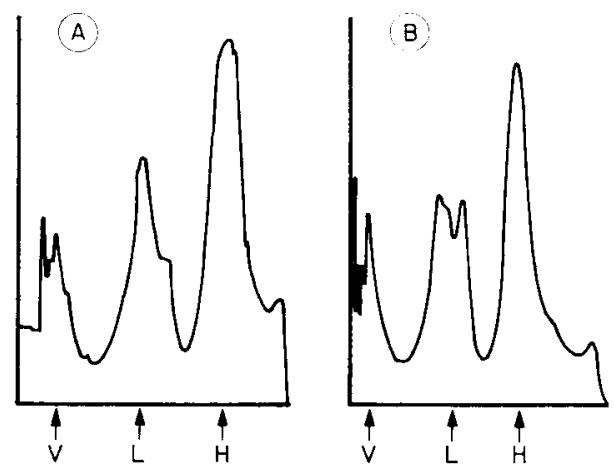

FIG. 1. - Optical density of lipoproteins floated through $\mathrm{KBr}$ gradients $(1006<\mathrm{d}<1.21)$ recorded at $280 \mathrm{~nm}$. (A) Lipoproteins from a pig reintroduced with its own bile. (B) Lipoproteins from a non reintroduced pig. $V: V L D L, L: L D L, H: H D L$.

TABLE 1

Digestive efficiency of lipids in swine with biliary fistulae

\begin{tabular}{|c|c|c|c|}
\hline \multirow{2}{*}{ Animal } & \multicolumn{3}{|c|}{ Duodenal reintroduction } \\
\hline & Bile $\left({ }^{(1)}\right.$ & $O\left({ }^{2}\right)$ & Salts $\left({ }^{3}\right)$ \\
\hline $\begin{array}{l}\text { A } \ldots \ldots \ldots \\
\text { B } \ldots \ldots \ldots \ldots \\
\mathbf{C} \ldots \ldots \ldots \ldots \\
\mathbf{D} \ldots \ldots \ldots \ldots \\
\mathbf{E} \ldots \ldots \ldots \ldots \\
\text { Mean } \pm \text { SEM. }\end{array}$ & $\begin{array}{c}47.9 \\
81.3 \\
58.0 \\
77.3 \\
66.6 \pm 7.6\end{array}$ & $\begin{array}{c}31.7 \\
45.4 \\
25.3 \\
65.4 \\
51.6 \\
43.9 \pm 7.1 *\end{array}$ & $\begin{array}{c}33.4 \\
64.6 \\
33.2 \\
38.8 \\
47.1 \\
43.4 \pm 5.9 *\end{array}$ \\
\hline
\end{tabular}

* Significantly different from animals reintroduced with bile $(p<0.05)$.

(1) Return of bile into the duodenum.

${ }^{(2)}$ No return either of bile or of salt solution.

(3) Return of a salt solution into the duodenum ( $\left.\mathrm{Na}: 150 \mathrm{meq} / 1 ; \mathrm{Cl}: 120 \mathrm{meq} / \mathrm{l} ; \mathrm{HCO}_{3}: 40 \mathrm{meq} / \mathrm{l}\right)$. 


\section{Results and discussion.}

\section{Lipid digestive efficiency.}

Table 1 shows that total diversion decreased lipid digestion. Individual variations were wide, however, and the two groups overlapped with values ranging from 49.7 to 81 p. 100 in reintroduced controls, and from 25.3 to 65.4 p. 100 in bile-deprived animals.

\section{Serum lipids (table 2)}

None of the lipid components measured were significantly affected by biliary diversion and the ensuing decrease in digestive efficiency. Cholesterol concentration did not greatly decrease despite the losses due to the interruption of the entero-hepatic cycle. Although there was a decrease in phospholipid levels, it was not significant owing to the wide individual variation.

\section{TABLE 2}

Serum lipids (mg per $100 \mathrm{ml}$ )

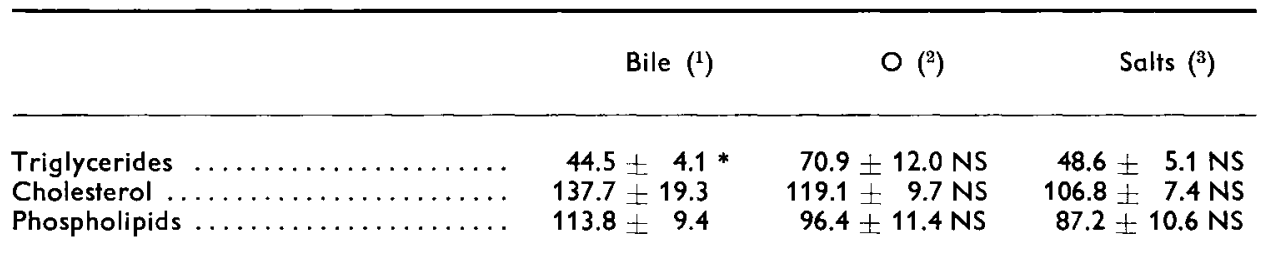

* Mean of 5 determinations \pm SEM. $\left({ }^{1}\right),\left({ }^{2}\right),\left({ }^{3}\right)$ as in table 1 . NS not statistically different from bile reintroduced controls.

\section{Plasma lipoproteins}

The small amounts of very low-density lipoproteins (VLDL) (table 3) were not affected by diversion. In contrast, low-density lipoproteins (LDL) significantly increased.

TABLE 3

Serum lipoproteins (mg protein per $100 \mathrm{ml}$ )

\begin{tabular}{|c|c|c|c|}
\hline Lipoprotein class & Bile $\left(^{1}\right)$ & $O\left({ }^{2}\right)$ & Salts $\left({ }^{3}\right)$ \\
\hline 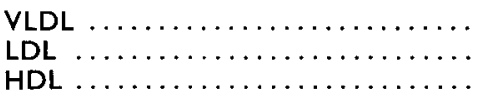 & $\begin{array}{l}3.6 \pm 0.7 * \\
26.0 \pm 2.5 \\
97.5 \pm 15.8\end{array}$ & $\begin{array}{l}5.0 \pm 1.0 \mathrm{NS} \\
45.9 \pm 2.7 \mathrm{NS} \\
52.9 \pm 9.6 * *\end{array}$ & $\begin{array}{r}2.3 \pm 0.3 \mathrm{NS} \\
33.2 \pm 1.7 \mathrm{NS} \\
69.4 \pm 14.1 * *\end{array}$ \\
\hline
\end{tabular}

* Mean \pm SEM of 5 samples ; ** significantly different from bile reintroduced controls $(p<0.05)$. (1), ( $\left.{ }^{2}\right),\left({ }^{3}\right)$ as in table 1. 
Considering the increased production of triglyceride-rich lipoproteins after partial diversion in the monkey (Adler et al., 1978), the results obtained here imply an accelerated catabolism of VLDL and larger entry into LDL. It would be interesting to determine if the stimulation of cholesterol synthesis, necessary to maintain cholesterol balance, is accompanied or not by stabilization of both the circulating cholesterol and its LDL carrier.

High-density lipoproteins (HDL) were of the same order in bile-supplemented animals as in normal unoperated ones (ca. $100 \mathrm{mg} / 100 \mathrm{ml}$, unpublished data). Bile diversion lowered the amount of circulating HDL by 30 to 40 p. 100 (table 3). Wide individual variations were again observed and the levels decreased from as much as 65 to only 10 p. 100 . Polyacrylamide SDS gel analysis of the delipidated lipoproteins showed no striking differences in the apoprotein composition of VLDL, LDL or HDL.

Correlation between digestive efficiency and high-density lipoprotein concentrations.

When all the animals were treated as one group, both plasma phospholipids and HDL concentrations evidenced a highly significant correlation with digestive efficiency (fig. 2). Correlation coefficients were $r=0.7572$ and $r=0.8002$, respectively $(P<0.01)$. Since HDL are the main phospholipid carriers in serum, it is not surprising that they both have a similar relation to digestive efficiency.

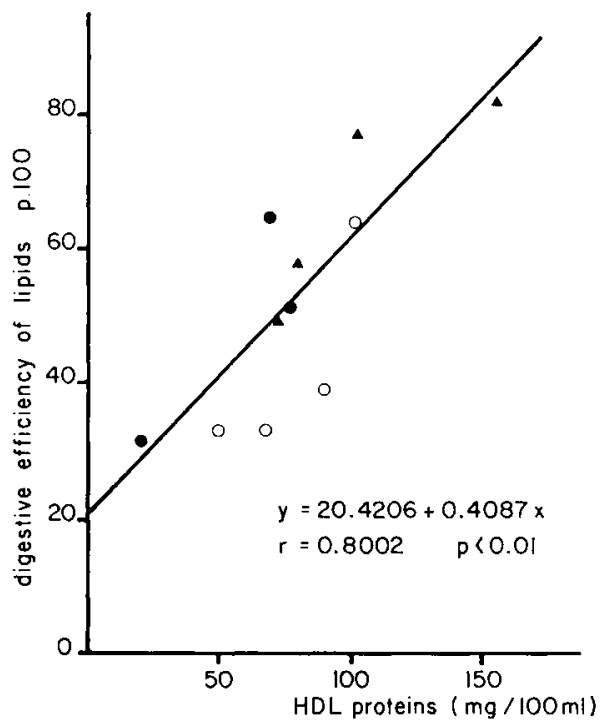

FIG. 2. - Correlation of individual values for digestive efficiency during a 10-day period and HDL concentrations at the end of the same period. Closed triangles : bile reinfroduction; Open circles : salt solutions; Closed circles : no reintroduction.

If the experimental procedure is used as a means of obtaining a wide variety 0 digestive coefficients, a definite relationship appears between these and the HDL concentrations, irrespective of the amount of bile in the intestine. It cannot be determined whether the primary alteration concerns phospholipids or apoprotein produc- 
tion. The fact that lipid synthesis seemed to satisfactorily compensate for the lack of absorption, rather pointed to a defect in apoprotein synthesis. Glickman and Green (1977) have recently described the rat intestine as an important source of $A l$, the main HDL peptide. Intestinale production of Al seems to be linked with intestinal lipid agsorption. We believe that the correlation between lipid digestive efficiency and HDL concentrations is a good indication that, under in vivo conditions, the intestine is a major contributor to the HDL pool in swine.

Commission CNERNA Digestion-Absorption/Association des Physiologistes, Paris 5-6 octobre 1978.

Résumé. L'étude a porté sur 5 Porcs Large White de $55 \mathrm{~kg}$ munis de fistules biliaires permanentes. Au cours de périodes successives de 8 jours chaque animal a soit subi une dérivation totale soit reçu en réintroduction duodénale sa propre bile ou une solution d'électrolyte. La digestibilité des lipides a été suivie pendant les 5 derniers jours de chaque période. Les lipides et lipoprotéines plasmatiques ont été mesurés le dernier jour de chaque période. Les coefficients d'utilisation digestive des lipides totaux solubles sont abaissés par la dérivation biliaire compensée ou non. La baisse modérée et non significative des taux de cholestérol indique une bonne compensation de la perte par la synthèse. Les phospholipides diminuent dans les mêmes proportions. Cette diminution s'accompagne d'une baisse significative des HDL $(p<0,05)$ chez les animaux privés de bile. II existe une corrélation hautement significative entre le coefficient de digestibilité des lipides et d'une part le taux de phospholipides plasmatiques, d'autre part la teneur en HDL. II semble donc exister des liens étroits entre absorption lipidique, phospholipides circulants ef HDL plasmatiques. Nous émettons l'hypothèse qu'une part non négligeable des HDL est synthétisée dans la paroi infestinale au cours de l'absorption.

\section{References}

ABELL L. L., LEVY B. B., BRODIE B. B., KENDALL F. E., 1952. A simplified method for the estimation of total cholesterol in serum. J. biol. Chem., 195, 357-366.

ADLER R., MARGULES E., MOISON R., WAY L., OCKNER R., 1978. Increased production of triglyceride-rich lipoproteins after partial biliary diversion in the Rhesus monkey. Metab., 27, 607-613.

BARTLETT G. R., 1959. Phosphorus assay in column chromatography. J. biol. Chem., 234, 466-468.

GLICKMAN R. M., GREEN P. H. R., 1977. Intestine as a source of Al apolipoprotein. Proc. nat. Acad. Sci. (US), 74, 2569-2573.

LOWRY O. H., ROSEBROUGH N. J., FARR A. L., RANDALL R. J., 1951. Protein measurement with the Folin phenol reagent. J. biol. Chem., 193, 265-275.

SHEFER S., HAUSER S., LAPAR W., MOSBACH E. H., 1972. Hydroxymethylglutaryl coenzyme A reductase of infestinal mucosa and liver of the rat. J. Lip. Res., 13, 402-412. 